\title{
Corrigendum: Augustinus: 'n Studie oor die etiek van die kerkvader uit Afrika deur J.H. van Wyk
}

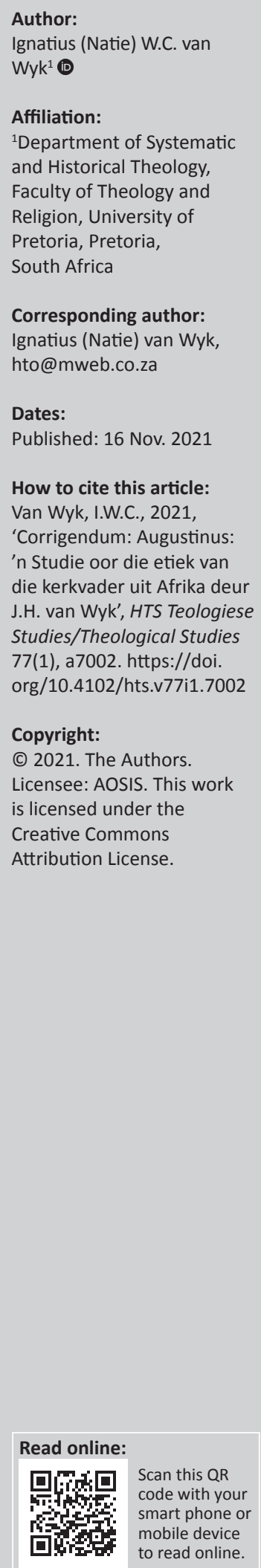

Scan this QR code with your smart phone or mobile device to read online.

In the version of the article initially published, Van Wyk, I.W.C., 2019, 'Augustinus: 'n Studie oor die etiek van die kerkvader uit Afrika deur J.H. van Wyk', HTS Teologiese Studies/Theological Studies 75(4), a5560. https://doi.org/10.4102/hts.v75i4.5560, the reviewed book's publisher city was given incorrectly as SUN MeDIA, Bloemfontein. The correct city name should be Stellenbosch instead of Bloemfontein.

This correction does not alter the study's findings of significance or overall interpretation of the results. The author apologises for any inconvenience caused. 